\title{
EXPLORING EU COMPETENCE IN CFSP: LOGIC OR CONTRADICTION?
}

\begin{abstract}
Maja Brkan*
Summary: This paper discusses questions concerning the conferral of EU Member States' competences in foreign affairs to the Union and the consequences of such conferral. The importance of this question lies in the need for an accurate definition of the nature of the CFSP. By showing that the Union possesses genuine competences in the CFSP area, and through a definition of the characteristics of this type of competence, it will be demonstrated that the policy has moved beyond mere intergovernmental cooperation, and represents an intermediate stage between intergovernmentalism and supranationality. In light of the practice of targeting individuals by freezing their funds and assets, the paper also looks at the broadening of first-pillar competences for economic sanctions, and attempts to predict possible developments in the CFSP area in the future with regard to the conferral of competence.
\end{abstract}

The literature on the CFSP is voluminous and varied in focus. A great part of it discusses issues from a political science point of view; ${ }^{1}$ the legal literature has only shown an interest in these issues quite recently, ${ }^{2}$ with some of it assuming an international law ${ }^{3}$ stance towards the CFSP. The specificity of the CFSP lies in the fact that conducting a

\footnotetext{
" LL.B. (Ljubljana), LL.M. (NYU). Researcher, Faculty of Law, University of Ljubljana. The author would like to thank John Morijn and the editors of CYELP for their valuable comments on an earlier draft, as well as the participants of the conference Advanced Issues of European Law, 4th Session, held in Dubrovnik in 2006, for a stimulating discussion of this issue.

${ }^{1}$ A few examples are R Reinhardt (ed), Toward Political Union. Planning a Common Foreign and Security Policy in the European Community (Westview Press, Boulder 1992); N Winn and C Lord, EU Foreign Policy Beyond the Nation-State. Joint Actions and Institutional Analysis of the Common Foreign and Security Policy (Palgrave, New York 2001); M Holland (ed), Common Foreign and Security Policy. The First Ten Years (2nd edn Continuum, London 2004); S Nuttall, European Foreign Policy (Oxford University Press, New York 2000); KE Smith, European Foreign Policy in a Changing World (Polity Press, Cambridge 2005).

2 This is, however, beginning to change. The most vivid examples are probably RA Wessel, The European Union's Foreign and Security Policy (Kluwer Law International, The Hague 1999); P Eeckhout, External Relations of the European Union. Legal and Constitutional Foundations (Oxford University Press, Oxford 2004).

${ }^{3}$ See for example M Koskenniemi, 'International Law Aspects of the Common Foreign and Security Policy' in M Koskenniemi (ed), International Law Aspects of the European Union (Kluwer Law International, The Hague 1998) 19.
} 
purely legal analysis here is almost impossible without considering its actual policy and characteristics. Various authors differ greatly as to what kind of cooperation the CFSP actually represents, and whether the Union possesses genuine competences in this area. In this light, the purpose of this paper is a threefold one: first, to discuss and attempt to clarify the nature of the CFSP through a bottom-up approach, proceeding from the question of a conferral of competence ${ }^{4}$ in this area; second, to show how, in certain cases, first-pillar competences in economic sanctions need to be broadened in order to achieve second-pillar objectives; and third, to try and predict whether a further conferral of competence will be necessary in order to achieve a more effective CFSP.

The first part of the paper examines questions about whether a conferral of competence in the CFSP area has already taken place, what the conditions of such conferral are, and what type of competence, if any, the Union has in this area. It further discusses the link-up and interdependence between first- and second-pillar competences, in particular the use of first-pillar competences for the achievement of second-pillar objectives. The second part then elaborates on the problem of stretching first-pillar competences in trade and foreign policy with the goal of freezing individuals' funds and assets. This question, being more of a Community than a Union law matter, is important for issues concerning both the broader framework of intertwining the first and second pillars and the proliferation of second-pillar matters via first-pillar competences. The link between the first and second parts of this paper is, therefore, an important albeit implicit one, since it demonstrates that any shortcoming in the amount of competences conferred on the Union in the second pillar must be remedied by issuing first pillar acts. Whereas the first two parts of the paper examine competence questions as they currently stand, the paper concludes by discussing the CFSP's prospects in light of future conferrals of competence in this area. The third and final part thus proposes some characteristic features of the CFSP model in the future, in the awareness that agreement at the political level and a more coherent political identity $^{5}$ among the Member States are preconditions for further integration in this area. It considers the question of how much further the conferral of competence in the CFSP area should extend in order to make this policy more effective.

${ }^{4}$ This term is understood here broadly, as the competence to adopt measures in a particular area.

${ }^{5}$ On identity in the CFSP, see T Tiilikainen, 'Does Europe Need a Common Identity? A Comment upon the Core Problems of the CFSP' in Koskenniemi (n 3) 27. 


\section{The CFSP and conferral of competence}

It has been suggested in the literature that the terms "conferral" or "transfer" of competence are not appropriate for the CFSP, and that in this area "we are confronted with newly created competences rather than with 'transferred' competences". ${ }^{6}$ Instead, it has been proposed that the framing of the CFSP be regarded as the replacement of national foreign policies. ${ }^{7}$ However, it is difficult to see the precise difference between transfer or conferral, on the one hand, and the replacement of national competences, on the other. Replacement seems to suggest that competences are, in a given matter, no longer exercised at the national level, and to imply the reversibility of this newly-created competence. However, as will be shown later, conferral of a competence is, likewise, not preconditioned by its irreversibility. This paper uses the term "conferral" as a general term for the conferring of powers on a supranational entity. Such an approach is in accordance with the terminology used in the EC Treaty ${ }^{8}$ and with the most comprehensive research to date on the conferral of powers on international organisations, conducted by Dan Sarooshi, ${ }^{9}$ who uses "conferral" as a general term designating various types of conferral of competence.

\subsection{Theories on the nature of the Union and their inadequacy}

If discussed at all, the question of the conferral of competence in the CFSP area is usually dealt with as part of attempts to explain the nature of the Union and each of the pillars, using the method of deduction from a broader analysis of the nature of the Union and the second pillar to a (narrower) inference regarding the conferral of competence. Theories explaining the nature of the European Union may be classified in three separate categories. Yet it is not in the discrepancies between these different theories that their inadequacy lies, but rather in the common trap into which all of them fall. In what follows, the three different categories of theories ${ }^{10}$ explaining the nature of the Union on the continuum of integration ${ }^{11}$ are presented, together with a critique of each.

\footnotetext{
${ }^{6}$ Wessel (n 2) 254.

7 Ibid.

${ }^{8}$ Art 5(1), art 7(1), art 8, art 9 and art 13 TEC are only a few examples.

9 D Sarooshi, International Organizations and their exercise of Sovereign Powers (Oxford University Press, New York 2005).

${ }^{10}$ This classification was developed primarily by Birgit Weidel, although I have added certain elements. See B Weidel, 'Regulation or Common Position? The Impact of the Pillar Construction on the European Union's External Policy' in B Weidel and S Griller (eds), External Economic Relations and Foreign Policy in the European Union (Springer, Vienna 2002) 23, 38ff.

${ }^{11}$ It is perhaps less appropriate to see them as categories than as a continuum, designating different levels of integration.
} 
The first category of authors sees the Union as merely providing a forum for coordinated cooperation, ${ }^{12}$ and the second (and third) pillar as purely intergovernmental. ${ }^{13}$ The European Union, according to them, does not have legal personality, let alone constitute a legal system. The Member States, when they act within the second and third pillars, are not acting as members of an organisation, but rather in the capacity of contractual parties, and cooperation within the two pillars is binding solely under international law. ${ }^{14}$ These theories do not assign any importance to cross-pillar components of the Union, such as the common institutional framework and the principle of coherence among different policies and pillars. Consequently, the two intergovernmental pillars do not, in the view of these authors, represent any intention of the Member States to confer their competences to the EU in the given areas.

The second category of authors comprises theoreticians whose vision of the Union is as a body distinct from its Member States and the Community. ${ }^{15}$ It could be designated, as Weidel correctly observes, as a triangular structure of three different entities: the Community, the Member States, and the Union. With regard to the question of the conferral of competence, this category has two separate prongs. Advocates of the first prong negate the possibility of conferring powers to the Union: the Union is a "separate entity of integration and cooperation" which lacks competences of its own. ${ }^{16}$ Proponents of the second claim that a conferral of powers to the Union has already taken place, and that the Union is a "legal entity with genuine law-making powers". ${ }^{17}$

The third vision of the Union comprises theories advocating a unitary structure for it. ${ }^{18}$ The European Union constitutes a single legal system

\footnotetext{
${ }^{12}$ Weidel (n 10) 38, citing Pechstein and König, Die Europäische Union - die Verträge von Maastricht und Amsterdam (Mohr, Tübingen 1998).

${ }^{13}$ Koskenniemi (n 3).

${ }_{14}$ Koskenniemi (n 3) 30, citing I MacLeod, ID Hendry and S Hyett, The External Relations of the European Communities (Clarendon Press, Oxford 1996) 412: "As is well known, CFSP '...remains intergovernmental, subject to international law, not Community law. Its product is instruments governed by international law, not Community legislation.' "

15 Weidel (n 10) 40, citing T Heukels and JW de Zwaan, 'The Configuration of the European Union: Community Dimensions of Institutional Interaction' in D Curtin and T Heukels (eds), Institutional Dynamics of European Integration. Essays in Honour of Henry G. Schermers (Martinus Nijhoff Publishers, Dordrecht 1994) 195.

${ }^{16}$ Ibid.

17 Weidel (n 10) 44.

${ }_{18}$ Developed mainly by von Bogdandy following the Amsterdam Treaty and, in the aftermath of the Maastricht Treaty, by von Bogdandy and Nettesheim. See A von Bogdandy, 'The Legal Case for Unity: The European Union as a Single Organization with a Single Legal System' (1999) 36 CML Rev 887; A von Bogdandy and M Nettesheim, 'Ex Pluribus Unum: Fusion of the European Communities into the European Union' (1996) 2 European Law Journal 267.
} 
and an has international legal personality. The three pillars are not three separate legal systems, but are interconnected and embedded within the one system of the Union, forming three subsystems of a single legal system with partially specific legal instruments and procedures. ${ }^{19}$ The Community legal order thus "forms part of the Union's legal order". ${ }^{20}$ Certain authors even claim that there has been a "fusion" of different pillars into one Union. ${ }^{21}$ The main arguments in support of this set of theories are the single institutional framework of the EU; the fact that the budget is used for the whole Union; certain supranational elements in the second and third pillar, such as qualified majority voting in CFSP matters or preliminary rulings by the Court on police and judicial cooperation in criminal matters; protection of human rights throughout the Union; and the requirement of consistency among different subsystems. Authors in this category take the view that competences have been conferred to the Union.

The different models analysed above certainly have differing points of view as to whether a conferral of competence from the Member States to the Union has already taken place. Those who consider that the TEU did not create a union with the capacity to take legal action are of the opinion that no powers have been conferred to the Union, and that the second pillar consists of the "concerted exercise of Member States' competences". ${ }^{22}$ On the other hand, there are those who "recognise the Union as a legal entity with genuine law-making powers", ${ }^{23}$ and those who consider Community competences to be just one type of Union competence, such as von Bogdandy, who claims that "the essence of the pillar structure is nothing but a variation on the allocation of powers amongst the institutions". ${ }^{24}$

One of the aims of this paper is to pinpoint a common deficiency that all three groups of theories suffer from. When various authors speak about the conferral of competence to the Union in the second (and third) pillar, and the nature of the Union in connection therewith, they succumb to what may be termed the fallacy of (reverse) causality. Namely, it is erroneous to assume that the question of whether a conferral of competence in the second (or third) pillar has taken place should be an-

\footnotetext{
19 Von Bogdandy (n 18) 887.

${ }^{20}$ RA Wessel, 'The Constitutional Relationship between the European Union and the European Community: Consequences for the Relationship with the Member States' (2003) Jean Monnet Working Paper 9/03 <http://www.jeanmonnetprogram.org/papers/03/03090109.pdf>, iii.

${ }^{21}$ Von Bogdandy and Nettesheim (n 18).

${ }^{22}$ Weidel (n 10) 44.

23 Ibid.

${ }^{24}$ Von Bogdandy (n 18) 902.
} 
swered by first defining the nature of the Union, and not the other way round. Such an approach regards a conferral of competence as the consequence of a certain perception of the Union's structure, one for which the author has decided a priori based not on the conferral of competence, but on other elements. In other words, we submit that it is erroneous to argue that the conferral of competence is contingent upon what we preliminarily perceive to be the Union's structure: if we say that its structure is $\mathrm{X}$, we establish a conferral of competence, whereas if we perceive its structure to be Y, conferral presumably does not take place. An illustration of this fallacy may be found in the following citation: "If one looks at EU law as a single legal system, the discourse of transfer of competences, stemming from Van Gend en Loos, may also be appropriate for the second (and third) pillar. If, by contrast, one analyses the TEU provisions on CFSP through the prism of international law, there may be less scope for such a discourse, which is not commonly known in international law." 25 We claim that such a mode of argumentation confounds the cause with the consequence. Of course, on a meta-level it is not contested that particular perceptions and models of the nature of the Union might have particular consequences. From a constitutional point of view, however, the conferral of competence should be viewed as a cause for a certain constitutional structure and a certain nature of an entity, rather than their consequence. Conferral is one of the factors which determines this structure, rather than being determined by it; likewise, it directs and shapes a perspective on this structure, rather than being directed and shaped by one. To put it more bluntly, the question of whether second-pillar competences have been conferred to the Union should be answered prior to determining the nature of the second pillar and/or the Union. Instead of the deductive approach taken by the authors cited above, an inductive, bottom-up approach should be used: the conferral of competence is one of the foundations upon which the nature of an organisation should be formed. This is, of course, not the only feature that should serve as a basis for determining the nature of an entity; rather, it is only one of several, as has been suggested in a similar argument regarding the third pillar. ${ }^{26}$ However, we would argue that it is the most important one.

\footnotetext{
${ }^{25}$ Eeckhout (n 2) 144.

${ }^{26}$ Neil Walker seems to suggest that determining whether certain cooperation among the Member States is to be designated as "intergovernmental" depends on various factors, one of them being the "location of competence (extent of European law-making and executive jurisdiction, and whether exclusive or shared)". Other factors include "right of initiative", "procedure for adoption", "intensity of measures adopted", "mode of implementation", "justiciability" and "forms of post factum oversight". See N Walker, 'In Search of the Area of Freedom, Security and Justice: A Constitutional Odyssey' in N Walker (ed), Europe's Area of Freedom, Security and Justice (Oxford University Press, New York 2004) 3, 16.
} 


\subsection{Conferral of competence}

Setting out to explore the potential conferral of EU competences in foreign policy matters requires answers to some preliminary questions. First, we must define, in an abstract manner, when a conferral of competence takes place and what the indicators of such a conferral are. Second, within the CFSP framework, we need to determine whether, in light of such a definition, Member States' competences in this area have already been conferred to the Union, and, if so, to which type of competence a CFSP competence belongs.

\subsubsection{Definition and conditions of conferral}

At first sight, the task of specifying the definition and conditions of a conferral of competence might seem utopian. One immediate argument against any such attempt lies in a concrete approach which questions the possibility of establishing objective criteria for conferral, casts doubt on whether the moment of conferral can be determined in advance and in the abstract, and claims that conferral can only be defined on a case-bycase basis and ex post facto. A similar approach is to argue that identical criteria for a conferral of competence cannot exist for the first and second pillar alike. However, we contend that it is possible to provide directions and indications regarding this issue, and to define which attributes must necessarily be present in order to establish a conferral of competence. A comprehensive theory on this issue with regard to international organisations in general was developed by Sarooshi. ${ }^{27}$ This paper takes his theory as its basis, while adding certain elements so that it may be applied to the CFSP area. Differing conceptions of when a conferral of competence takes place are possible; viewed broadly, these are the formal approach (express conferral by treaty) and the material approach (voting or institutional approach).

(1) Formal approach. Sarooshi claims that powers are usually conferred on an organisation by virtue of a constituent treaty. ${ }^{28}$ To support this view, he cites the International Court of Justice's WHO Advisory Opinion, ${ }^{29}$ in which the Court states that "[t]he powers conferred on international organisations are normally the subject of an express statement in their constitutional instruments". ${ }^{30}$ This could be termed the formal approach, according to which competences are conferred when so deter-

\footnotetext{
${ }^{27}$ Sarooshi (n 9).

${ }^{28}$ Apart from conferrals by constituent treaty, Sarooshi deals with conferrals on an ad hoc basis, whereby states conclude a treaty in order to confer powers on an organisation, and the organisation is obliged to agree; however, this model cannot be applied to the CFSP.

${ }^{29}$ Legality of the Threat or Use of Nuclear Weapons (Advisory Opinion) [1996] ICJ Rep 64.

30 Ibid para 25.
} 
mined by a treaty, i.e. when a treaty delimits them in terms of the level of the entity to which competences are conferred and the level of the states conferring them; or, in other words, when states formally cease to have exclusive competence in certain areas. However, this approach fails to resolve two problems. First, it cannot be absolute, as implied, judiciallydeveloped competences represent a necessary corollary to prior treatydefined ones. Second, this approach does not foresee situations where a conferral of powers takes place in an implicit and de facto manner. Moreover, Sarooshi does not give an answer to the question of just how "express" an express conferral of powers should be. Does this imply the use of words such as "conferral", "delegation", "transfer", "competences" or "powers"? Is it possible for a treaty not to use these particular terms and yet still confer powers to an international organisation?

The WHO Advisory Opinion does indeed recognise the possible existence of subsidiary competences despite the lack of any express statement regarding such competences in the constituent treaties, claiming that "the necessities of international life may point to the need for organisations, in order to achieve their objectives, to possess subsidiary powers which are not expressly provided for in the basic instruments which govern their activities", and that "it is generally accepted that international organisations can exercise such powers, known as 'implied' powers". ${ }^{31}$ It is important, however, not to confound CFSP competences with implied powers which are merely subsidiary and corollary to expressly conferred powers. CFSP competences are not subsidiary powers, but rather selfstanding and independent of other types of competence. Second-pillar competences should, therefore, be strictly delimited from external implied powers in a Community law sense. While Community external implied powers parallel the exercise of internal powers, CFSP competences should be treated as a separate category of competence. The WHO Advisory Opinion therefore points to a less formalistic solution, but only refers to non-express subsidiary powers.

As already indicated with reference to CFSP competences, some hesitation occurs regarding the degree of formalism. On the one hand, if this issue is approached in a highly formalistic manner, it could be claimed that the TEU does not, in fact, use the express term "conferral of powers" and does not define anything explicitly with regard to this matter. The TEU states that "the Union shall define and implement a common foreign and security policy" (Article 11(1)), but does not specify that this is the Union's competence. A formalistic approach would require the Treaty to state explicitly that the Union "shall have the competence" to define and implement the CFSP. On the other hand, if "express" conferral is not un-

${ }^{31}$ Emphasis added, ibid. 
derstood in such a strict manner, it may be claimed that the TEU clearly distinguishes between the Union and its Member States: it is the Union that defines and implements the CFSP and pursues an external and security policy (Article 11) and the CFSP objectives (Article 12). Despite the fact that there is no mention in the TEU of the Union's competence, but rather only that the Union is to define and implement a common foreign and security policy covering all the relevant areas, it should be stressed that it is not simply the community of Member States that defines and implements the CFSP. The Member States are actors who should support the Union's foreign and security policy and refrain from actions contrary to the interests of the Union (Article 11). We would argue that this second, less rigid approach should be adopted. This clear delimitation between the Union and its Member States is the first indication and argument in favour of the thesis that Member States' competences have been conferred to the Union in the CFSP area.

Nevertheless, even if express conferral is interpreted in a very rigid manner, so that, based on this criterion, no conferral of competence is established, it still might be possible to determine that such a conferral has occurred, provided that we do not regard this criterion as the only threshold for actual conferral. In other words, the criteria that Sarooshi uses for determining the type of competence can also be used to determine whether a conferral of competence has taken place when a treaty contains no express statement regarding the same. Sarooshi speaks of three criteria for determining the type of competence: revocability of powers, control over the exercise of powers, and exclusive or concurrent competence to exercise the conferred powers. The first criterion, revocability of powers, cannot be determinative for the issue of conferral, as Sarooshi himself states. The most important of the three criteria, for the EU in general and the CFSP in particular, is that of control over the exercise of powers. Here again, a question arises as to what parameters determine the degree of control: is it a type of voting, with the possibility of opting out of an act, or another form of loss of control? We submit that, for the second pillar, two criteria are crucial for determining a loss of control: voting, and the independence of the institution adopting the acts.

(2) Voting approach. The voting approach has two prongs, positive and negative. According to the positive voting approach, conferral is said to occur when decision-making ceases to be conducted by unanimity, regardless of the majority involved. Introduction of any type of majority vote, whether by a simple, qualified, or even higher majority, gives rise to an autonomous decision on a higher level of authority, implying a greater or smaller degree of independence among national positions. The negative voting approach suggests that decision-making with unanimity does not necessarily mean that competences have not been conferred. 
It is, for example, not valid to claim that there is no conferral of competence in areas where the Community decides by unanimity. In 1964, at the time of the Costa/ENEL decision, most measures were adopted by unanimity, ${ }^{32}$ yet the Court decided that "the Member States have limited their sovereign rights and have thus created a body of law which binds [...] themselves". ${ }^{33}$ Claiming that unanimity voting proves the absence of conferral of competence is thus problematic in and of itself, since exclusive application of this approach is insufficient to resolve the question of whether a conferral has taken place or not. For this reason, the voting approach needs to be complemented by another (institutional) approach, as elaborated below.

Despite this deficiency, it should be verified whether current examples of qualified majority voting (QMV) in the CFSP area suffice to establish a conferral of competence, given the fact that unanimity as a general rule for adoption of the CFSP can neither confirm nor deny conferral. QMV in the CFSP is possible only in three instances: (a) when adopting joint actions and common positions, or making any other decision based on a common strategy; (b) when adopting any decision implementing a joint action or common position; and (c) when appointing a special representative with a mandate related to particular policy issues. ${ }^{34}$ With regard to situation (a), it should be noted that common strategies are adopted by the European Council. Concerning situation (b), it should be borne in mind that joint actions and common positions are adopted unanimously by the Council, and that QMV for implementing these acts is thus only indirect, and depends upon a prior unanimously adopted act. With regard to situation (c), the Council may, according to Article 18(5) TEU, appoint a special representative with a mandate related to particular policy issues whenever it deems this necessary. Special representatives represent the EU in conflict areas and promote EU interests and policies. ${ }^{35}$ Their appointment is a decision concerning not the content of a CFSP action, but rather the person who will advocate the Union's interests in third countries and assist those countries. These three cases of QMV are, therefore, insufficient to establish a conferral of competence in this area.

\footnotetext{
${ }^{32}$ Unanimity was the predominant voting rule until 1966. See V Miller, 'The Extension of Qualified Majority Voting from the Treaty of Rome to the European Constitution' (2004) Research Paper 04/54 <http://www.parliament.uk/commons/lib/research/rp2004/rp04054.pdf $>3$.

${ }^{33}$ Case 6/64 Flaminio Costa v E.N.E.L. [1964] ECR 585 para 3.

${ }^{34}$ Treaty on European Union art 18(5).

${ }^{35}$ Examples of special representatives include those for the South Caucasus, Bosnia and Herzegovina, the Former Yugoslav Republic of Macedonia (FYROM), Central Asia, Sudan and Afghanistan. EU Council Secretariat, Factsheet, 'EU Special Representatives (EUSRs): A voice and face of the EU in crucial areas' (2005) <http://www.consilium.europa.eu/ uedocs/cmsUpload/EUSRs.pdf> 1.
} 
Furthermore, it should be determined whether unanimity voting, coupled with constructive abstention, indicates a certain degree of conferral of competence. Bradley and Kelley are of the opinion that this is not the case. ${ }^{36}$ According to them, in order for conferral (which they term "international delegation of authority") to take place, "the state must lack full formal control over the decisions or actions of the entity" ${ }^{37}$ In their view, "full formal control means that no binding decision or action can be taken without the affirmative vote or purposeful abstention of the state through a vote". ${ }^{38}$ As already stated, we maintain the view that unanimity voting per se cannot exclude the possibility of powers being conferred. It may merely indicate a lack of conferral, but does not constitute an ultimate proof; instead, this must be proved using other approaches. We would, however, agree with the view that the existence of constructive abstention does not contribute in any respect to an affirmative answer as regards the conferral of powers. Sarooshi points to a different example: when an international organisation adopts binding decisions by a majority vote, and its member states have the right "to contract out of, or make reservations to," this decision before it enters into force, a conferral has still taken place. ${ }^{39}$ This example is inherently different, however, since the acts were adopted by a majority vote.

(3) Institutional independence approach. Decisive proof of a conferral of powers in the CFSP area can be obtained via the institutional independence approach. According to this approach, a conferral of competence takes place when a decision is made on a higher level by an institution which is more than just the sum of its members, as in the case of the EU and its Member States. This approach builds on the argument that the Council is not merely a forum for meetings by the Member States' government representatives, but an institution which, albeit composed of member states, is still relatively independent ${ }^{40}$ of them. The mere fact that CFSP acts are adopted within the framework of the Council indicates that this is a Union-level competence, and thus that competences are not held entirely by the Member States. The nature of the Council as an institution cannot be denied, and it would be illogical for it to act as an

\footnotetext{
${ }^{36}$ CA Bradley and JG Kelley, 'The Concept of International Delegation' (2006) Duke Workshop on Delegating Sovereignty <http://www.law.duke.edu/publiclaw/pdf/workshop06sp/bradleykelley.pdf> 3 .

37 Ibid.

${ }^{38}$ Ibid.

${ }^{39}$ Sarooshi (n 9) 59. He states that, in this case, the type of competence conferred is delegation, not transfer.

${ }^{40}$ Although Wessel rejects the use of the concept of "transfer" for the CFSP, he uses the criterion of independence when seeking to establish a distinction between an entity and its members: "What we look for are the minimum features of an international entity to conclude on some degree of independence vis-à-vis its member states". Wessel (n 2) 254.
} 
institution when deciding within the Community, but merely as a forum for the Member States, who retain their exclusive competence, in matters concerning the second pillar. The obvious counterargument is, of course, that a first-pillar conferral is not due to decision-making by the Council, but rather to other factors, such as QMV, primacy, and the effective enforcement of Community measures. We submit, however, that the effect or enforcement of a measure should not be confused with the level at which it is adopted. These two phenomena are - and should be - separate from one another. As far as QMV is concerned, we have seen that it is not a sufficient indicator for whether conferral has taken place.

Further arguments in line with this approach may be found in the TEU itself. The Treaty states that institutions - the European Parliament, the Council, the Commission, the Court of Justice and the Court of Auditors - shall exercise their powers under the conditions and for the purposes set forth in the two treaties, i.e. the TEC and the TEU (Article 5(1)), thus implying that they have powers under the TEU as well. From where would they derive these powers if not from a conferral? One frequently heard argument in this regard concerns the common institutional framework by which the Union is to be served (Article 3(1)). It would be quite illogical for the same institutions, especially the Council, to have competences pursuant to the EC Treaty, but not the EU Treaty, including the CFSP. Using the institutional approach, it may be demonstrated that a conferral of competence in the CFSP area has indeed taken place. It is important to note that pre-emption or "occupation" of this area is not a condition for conferral to occur, as will be explained below.

\subsubsection{CFSP competence: a hybrid}

Once it has been determined that a conferral has taken place, we need to decide which type of competence it should qualify as. It is patent that the type of competence found in the CFSP area should be sought somewhere on the scale between concurrent ${ }^{41}$ and complementary competences. We would argue that the current list of three categories of competence - exclusive, concurrent and complementary ${ }^{42}$ - is not exhaus-

${ }^{41}$ One synonym for "concurrent competence" which is sometimes used is "shared competence". We would caution against the use of this term, since it is used for different types of competence by different authors, and may thus create confusion.

${ }^{42}$ A slightly different classification has been proposed by von Bogdandy and Bast, who distinguish between exclusive and non-exclusive competences and, within the latter category, between concurrent, parallel (or shared) and non-regulatory powers, with parallel powers having the same content as complementary ones. A von Bogdandy and J Bast, 'The European Union's Vertical Order of Competences: The Current Law and Proposals for its Reform' (2002) 39 CML Rev 227, 242. 
tive. Each type of competence implies a different degree of conferral, and reflects different characteristics. For the purpose of contextualising this problem, a short excursus on the three current types of competence is necessary. As a preliminary, it should be mentioned that the text of the EC Treaty distinguishes only between exclusive and non-exclusive competences (Article 5(2) EC). There is no mention of complementary competences anywhere in the Treaty; yet this category exists, although it is not called by that name in the TEC. ${ }^{43}$

Exclusive competence, as developed by the ECJ and formally introduced into the TEC by the Maastricht Treaty (in what is now Article 5(2) EC) ${ }^{44}$ implies that, in an area where the Community has exclusive competence, the Member States are not allowed to adopt legislative acts or conclude treaties with third countries, regardless of whether such a competence has been exercised by the Community or not. Concurrent competence implies that the Member States can act in a particular area only as long as the Community has not done so; once the EC has adopted legislation which enjoys primacy over a conflicting national law, the Member States are barred from adopting any legislation in the given area. This is sometimes also referred to as "occupation" of the area, whereby the Member States are prevented from adopting legislation in accordance with the principle of "pre-emption". Complementary competence means that the Community has the competence to complement and support the Member States' action in a particular area, while the Member States are not barred from exercising their own competence even after the Community has adopted acts; the exercise of Community competences thus does not result in "pre-emption". ${ }^{45}$ Examples of such competence in the TEC are found in Articles 149, 164 and 157 EC. The fact that the Community does not occupy the area in question is the main difference from concurrent competence. The three current categories of competence do not, however, constitute an exhaustive list of the existing competences; they are not rigidly defined, nor are they the only possible types of competence. As has already been pointed out elsewhere, "the process of integra-

\footnotetext{
${ }^{43}$ This term came into use during preparations for the Constitutional Treaty. See, for example, the "Final Report of Working Group V "Complementary Competencies"' (2002) CONV 375/1/02, REV 1, WG V 14 <http://register.consilium.eu.int/pdf/en/02/cv00/00375r1en2.pdf>.

${ }^{44}$ Formerly art 3b EC.

${ }^{45}$ Hable argues that exclusion of pre-emption is the essential dividing line between concurrent and complementary competence, although she uses different terminology to designate the types of competences. A Hable, 'The European Constitution: Changes in the Reform of Competences with a Particular Focus on the External Dimension' (2005) Europainstitut, Wirtschaftsuniversität Wien, EI Working Paper Nr. 67 <http://fgr.wu-wien.ac.at/wp/wp67. pdf>, 12 .
} 
tion does indeed entail the progressive creation of new powers, as well as the reorganisation of existing powers at both levels of governance". ${ }^{46}$

As a preliminary, it is necessary to define some characteristics of the CFSP competence, which is said to be located on the scale between concurrent and complementary competence. First, what is actually being conferred in this type of competence is the competence to decide in foreign policy matters. However, such conferral only occurs if there exists the political will to do so. ${ }^{47}$ This is possible because conferral in the CFSP area, unlike conferral in the case of concurrent competence, is reversible. A second important characteristic is that measures adopted within the CFSP framework do not pre-empt action by the Member States in a general way. With regard to the CFSP competence, even if the Union has acted in this area it is not occupied by it, and the Member States may still act. They are only required not to adopt measures that would conflict with the CFSP measures already adopted. Pre-emption thus does not constitute a rule in the CFSP, and this is its main similarity with complementary competence, where a Community competence can likewise be exercised alongside the competence of the Member States.

There has been much confusion among advocates of the view that the Union possesses competence in the CFSP area as to what type of competence this actually is. Before adoption of the Constitutional Treaty (CT), this confusion had literally gone to extremes, with, on the one hand, a Praesidium discussion paper claiming that "the powers of the Union in the CFSP area are concurrent with those of the Member States", ${ }^{48}$ while, on the other, a report stated that Union powers in the second pillar were "of an overwhelmingly intergovernmental nature". ${ }^{49}$ Others argued that the CFSP fit within what they termed "parallel" competences, corresponding contentwise to what were later called complementary competences, without giving any further justification or explanation as to why they

\footnotetext{
${ }^{46}$ I Pernice, 'Rethinking the Methods of Dividing and Controlling the Competencies of the Union' (2001) Walter Hallstein-Institut Paper 6/01 <http://www.rewi.hu-berlin.de/WHI/ english/papers/whipapers601/index.htm> 3.

${ }^{47}$ It would be wrong to say that a conferred competence is only exercised when there is political will.

${ }^{48}$ Praesidium discussion paper entitled 'Delimitation of competence between the European Union and the Member States - Existing system, problems and avenues to be explored (2002) CONV 47/02 <http://register.consilium.eu.int/pdf/en/02/cv00/00047en2.pdf> 6.

${ }^{49}$ Apart from expressing a point of view, this statement also contains an internal contradiction, for how can a power assigned to a supranational entity (Union) be at the same time intergovernmental? Intergovernmentality inherently implies that no power is allocated at the supranational level, thus remaining exclusively with states. See European Parliament Committee on Constitutional Affairs 'Report on the division of competences between the European Union and the Member States' (2002) 2001/2024(INI), A5-0133/2002 <http:// european-convention.eu.int/docs/relateddoc/511.pdf> 29.
} 
belonged in this category. ${ }^{50}$ Similarly, second-pillar powers were ranked among powers for "co-ordination and common action". ${ }^{51}$ Contrary to this view, there was also the opinion that CFSP powers should actually be placed among shared or concurrent powers. ${ }^{52}$

Following adoption of the Constitutional Treaty, the fog enveloping the CFSP competence partially lifted, yet its precise content and scope still remain unclear. In Article I-12, the CT differentiates between five categories of competence: namely, exclusive competence; shared competence; coordination of economic and employment policies; competence in matters of common foreign and security policy; and supporting, coordinating or complementary action. Many authors commenting on the issue of CT competences took the view that the CFSP here was - or had become - a "special", "separate" or "sui generis" type of competence. However, there was still a divide between those who willingly accepted it as a category separate from the three basic types of competence, and those who regarded the creation of a special category of competence as erroneous, claiming that it should instead be conceived of as a shared (also termed "concurring") competence, or a special sub-type thereof. Griller, for example, adheres to the latter position, stating that, instead of creating a special type of competence, the CFSP should have been categorised under shared (concurrent) competences, with the possibility of regulating its specificities, such as, for example, excluding direct effect and supremacy; this he compares to the current Article 34(2)(c) TEU, which excludes direct effect for any other decisions adopted pursuant to the provisions on police and judicial cooperation in criminal matters. ${ }^{53}$ Among advocates of the opposing position, Petersmann observes that CFSP competences as regulated in the $\mathrm{CT}$ represent a "special category of competences sui generis [...] whose constitutional regulation remains imprecise in many ways". ${ }^{54}$ Hable speaks of a "separate competence category for the CFSP" in the Constitutional Treaty, which allegedly "displays the reluctance to apply either of the legal consequences attached to the categories of shared competences or the area of supporting, coordinating or complementary

\footnotetext{
${ }^{50}$ Von Bogdandy and Bast (n 42) 247.

${ }^{51}$ Pernice (n 46) 5, 15.

${ }^{52}$ B de Witte, 'Clarifying the Delimitation of Powers - A Proposal with Comments' in Europe 2004 Le grand débat. Setting the Agenda and Outlining the Options (European Commission, Brussels 2002) 121, 129. According to de Witte, competence in defence matters would be a complementary competence.

53 S Griller, 'External Relations' in B de Witte (ed), Ten Reflections on the Constitutional Treaty for Europe (EUI Robert Schuman Centre for Advanced Studies, San Domenico di Fiesole 2003) 133, 139ff.

${ }^{54}$ E-U Petersmann, 'A New Constitutional Paradigm?' in C Gaitanides et al (eds), Europa und seine Verfassung (Nomos Verlagsgesellschaft, Baden-Baden 2005) 176, 184.
} 
action to the CFSP". ${ }^{55}$ Dashwood treats "competence to frame and implement the CFSP" as a separate category, one "obeying a different logic". ${ }^{56}$ Bermann speaks of the Union's powers in the CFSP area as not being found in any of the three categories ("as if an autonomous category"), yet does not explain why they should not actually be viewed as an autonomous category. ${ }^{57}$ Wessel treats this competence as a "CFSP competence", separating it from explicit and implicit external competences. ${ }^{58}$ All these different views show that the CT failed to clarify what characteristics this type of competence has, and that the issue of its precise scope and effects remains unclear. In any case, the Constitutional Treaty has been buried, pending further steps to revive it. The reason for discussing it here is that it reflects the current stage of Union integration and heralds its future development. The Treaty's reference to "competence to define and implement a common foreign and security policy" leaves us with three possibilities as to what actually occurred in the CT with regard to the CFSP.

The first possibility is that the Constitutional Treaty merely codified the current situation in this matter. The CT expressly states that the Union has competence in CFSP matters. ${ }^{59}$ This represents a large step with regard to the criterion of express conferral of powers by a constituent treaty, as discussed above, since conferral as formulated by the CT clearly falls within the category of expressly conferred powers. But even a less explicit formulation could still signify actual conferral, and it may be argued that the CT finally made explicit what was already in place. The second possibility is that the Constitutional Treaty has taken a decisive step towards finally creating CFSP competences on a supranational level, in an area where the competence issue was inherently unclear. We submit, however, that this is not the case, for the reasons stated above. Under the third possibility, it could be argued - although we do not agree

\footnotetext{
${ }_{55}$ Hable (n 45) 25. Hable argues, on the one hand, that the pre-emption embedded in shared competence has discouraged Member States from applying this type of competence to the CFSP and, on the other hand, that simple exclusion of pre-emption is not a solution either. Further, with regard to categorizing the CFSP as a complementary competence, she argues that this would represent "a poor signal on the way to developing a strong CFSP".

${ }^{56}$ A Dashwood, 'The Relationship Between the Member States and the European Union/ European Community' (2004) 41 CML Rev 355, 370.

57 Emphasis added. GA Bermann, 'Competences of the Union' in Tridimas and Nebbia (eds), EU Law for the 21st Century: Rethinking the New Legal Order (Hart Publishing, Oxford 2004) 65, 68.

${ }^{58}$ RA Wessel, 'Fragmentation in the Governance of EU External Relations: Legal Institutional Dilemmas and the New Constitution for Europe' in JW de Zwaan et al (eds), The European Union. An Ongoing Process of Integration. Liber Amicorum Alfred E. Kellermann (T.M.C. Asser Press, The Hague 2004) 123, 126.

59 Treaty establishing a Constitution for Europe art I-12(4) expressly states: "The Union shall have competence to define and implement a common foreign and security policy, including the progressive framing of a common defence policy."
} 
with this view - that the Constitutional Treaty does not reflect the real situation, that it has not created any special competence, and that, by not including the CFSP under any other competence, it only indicates that the Member States have retained their competences in this area. According to this view, the provisions regarding the Union's competence are merely words on paper. The position advocated in this paper adheres to the opinion of several authors who, following adoption of the Constitutional Treaty, advocated the view that the CFSP competence formed a separate, sui generis type of Union competence. However, it should be emphasised here that a future push towards concurrent competence in the CFSP area cannot be excluded. We have designated the CFSP type of competence as a convergent competence in order to signify a middle phase between exclusive and concurrent competence, one in which the Member States strive for a common result or conclusion. ${ }^{60}$ The term convergent is also more appropriate for indicating the non-reversibility of this type of competence, since it does not imply a "sharing" of power as the terms "concurrent" or "shared" competence do. The next section of this paper deals with the question of why it is important to discuss competence issues in the CFSP area.

\subsection{Consequences of the conferral of competence}

A discussion of the type of the CFSP competence should aim at identifying its consequences for the form of cooperation in CFSP matters and the nature of the second pillar. As mentioned at the outset, the existence and type of a competence is the main indicator of the nature of the relationship between the Union and its Member States. The type of this competence is, therefore, not a self-contained question; rather, it serves as the cause of a certain constitutional structure for CFSP cooperation. What follows in this part of the paper is an outline of this structure as the consequence of a given type of competence (as its cause). For this purpose, several stages in the formation of a political union will be briefly introduced, and the CFSP will be situated among these stages.

The formation of any union occurs in several stages; a customs and monetary union is a typical example of this phenomenon. Similarly, the formation of a political union among states does not occur instantaneously, but rather is a successive process, where it is not possible to advance to a later stage without first attaining the previous one. The stages of formation of a political union correspond to the degree of competences conferred to the supranational level. The scheme presented below builds

\footnotetext{
60 One of the meanings of the term "converge" is "to tend toward a common result or conclusion", as stated in Random House Webster's College Dictionary (Random House, New York 1991) 298 under the entry "converge".
} 
on the type of competence characteristic of a particular stage of integration, from which the form of cooperation among member states is derived. This method follows the bottom-up approach mentioned at the beginning, in order to avoid the fallacy of (reverse) causality.

Table 1: Stages in the formation of a political union ${ }^{61}$

\begin{tabular}{|l|l|l|}
\hline Type of competence & $\begin{array}{l}\text { Stage of } \\
\text { integration }\end{array}$ & Form of cooperation \\
\hline $\begin{array}{l}\text { Exclusive competence of } \\
\text { the actors }\end{array}$ & Information & $\begin{array}{l}\text { The actors inform each } \\
\text { other of the measures they } \\
\text { are adopting. }\end{array}$ \\
\hline $\begin{array}{l}\text { Exclusive competence } \\
\text { of the actors, seeking } \\
\text { coherence where possible }\end{array}$ & Consultation & $\begin{array}{l}\text { The actors inform each } \\
\text { other of their measures, } \\
\text { deliberate, and promote } \\
\text { coherence. }\end{array}$ \\
\hline $\begin{array}{l}\text { Exclusive competence of } \\
\text { the actors, but exercised } \\
\text { with a view to finding } \\
\text { common solutions where } \\
\text { the political will exists }\end{array}$ & Coordination & $\begin{array}{l}\text { The actors are involved in } \\
\text { multilateral negotiations } \\
\text { that result in international } \\
\text { treaties; some of their } \\
\text { measures are already } \\
\text { harmonised. }\end{array}$ \\
\hline $\begin{array}{l}\text { Concurrent competence } \\
\text { between the actors and } \\
\text { the supranational level }\end{array}$ & Harmonisation & $\begin{array}{l}\text { The next step from } \\
\text { coordination, where more } \\
\text { legislation is harmonised. }\end{array}$ \\
\hline $\begin{array}{l}\text { Exclusive supranational } \\
\text { competence }\end{array}$ & Unification & $\begin{array}{l}\text { Replacement of national } \\
\text { instruments with union } \\
\text { instruments. }\end{array}$ \\
\hline
\end{tabular}

As is readily apparent, the coordination stage does not fully explain the status quo of the CFSP, since, as was stated above, the Union already possesses competences in this area to a certain degree, and negotiations among the Member States do not result in international treaties. ${ }^{62}$ Those who claim that the Member States still remain exclusively competent in this area perceive the CFSP as currently being in the coordination stage and striving to move towards the harmonisation stage. However, it is difficult for them to explain the outcome of negotiations among the Member States; the only way that comes to mind is to assert that the results of

${ }^{61}$ This table logically follows from the one in P Grilc, Pravo Evropske unije (Pravna fakulteta and Cankarjeva založba, Ljubljana 2001) 11

${ }^{62}$ This is very well expressed by Wessel, who states: “...CFSP decisions are not to be seen as international agreements between [...] participating states, but rather as decisions taken by an organ of a new legal person composed of member states". Wessel (n 2) 324. 
negotiations are indeed not international treaties, but acts adopted on the basis of an international treaty. This should not, however, be confused with the adoption of international treaties themselves.

We would argue, therefore, that the convergent competence established above should be added to this table, which would be further amended as follows:

Table 2: Stages in the formation of a political union - proposed amendment

\begin{tabular}{|c|c|c|}
\hline Type of competence & $\begin{array}{l}\text { Stage of } \\
\text { integration }\end{array}$ & Form of cooperation \\
\hline$\ldots$ & Information & $\ldots$ \\
\hline$\ldots$ & Consultation & $\ldots$ \\
\hline ... & Coordination & $\ldots$ \\
\hline $\begin{array}{l}\text { Convergent } \\
\text { competence of } \\
\text { the entity and its } \\
\text { members, still } \\
\text { exercised only where } \\
\text { the political will exists }\end{array}$ & Synchronisation & $\begin{array}{l}\text { Decisions are made in the } \\
\text { framework of a pre-established } \\
\text { institution; the actors refrain } \\
\text { from any actions that could } \\
\text { jeopardise the objectives of } \\
\text { common action. }\end{array}$ \\
\hline$\ldots$ & Harmonisation & $\ldots$ \\
\hline$\ldots$ & Unification & $\ldots$ \\
\hline
\end{tabular}

The table now includes the convergent competence, with the characteristics elaborated above. However, this type of competence yields different consequences from those of exclusive competence in the coordination stage. Where a convergent competence exists, cooperation among the actors is no longer intergovernmental, since the entity itself begins to acquire a certain degree of independence, albeit still less than in the harmonisation stage. In the stage which we have termed synchronisation (because the members of an entity work together here to synchronise their actions and positions), the entity possesses pre-established institutions in whose framework decisions are made, and the actors are required to refrain from any actions that could jeopardise the objectives of an action adopted at the entity level. The synchronisation stage also shows where the CFSP is to be situated on the continuum of formation of a political union, and which stages it must pass through before full political union is achieved.

\section{Horizontal stretching of first-pillar competences}

Apart from the vertical conferral of competences, it is important to consider the horizontal stretching of first-pillar competences to issues 
with second-pillar objectives. The convergent competence in the second pillar has its limitations, and the competence in economic sanctions is encompassed by the first pillar, thus representing an interplay of competences in economic and foreign policy matters. Therefore, in order to gain a clear picture of foreign policy competence issues, it is also necessary to touch on recent developments regarding the first-pillar competence in economic sanctions.

The issue addressed in this section is the coupling of Article 308 EC, i.e. the flexibility clause, with Articles 301 and 60 EC; or, in other words, the possibility of applying Article 308 to Community economic sanctions. The Court of First Instance faced this legal problem in the recent Kadi $^{63}$ and Yusuff ${ }^{64}$ cases, in which regulations ${ }^{65}$ implementing Security Council resolutions ${ }^{66}$ freezing the funds of individuals and entities associated with the Taliban, Usama bin Laden and the Al-Gaeda network were challenged as ultra vires due to their having been adopted on the basis of these three articles. Under the regime currently in force, Article $308 \mathrm{EC}$ requires that measures adopted based thereon pursue one of the objectives of the Community, whereas Articles 60 and 301 EC state that the Council may impose urgent measures with regard to the movement of capital and payments and interrupt or reduce economic relations as regards third countries. The problem that arises in these cases is threefold.

The first problem concerns the more general question of simultaneous use of Articles 301 and 60, namely, determining whether economic sanctions pursue an objective of the Community or the Union. The core of this problem is that application of Article 308 to articles on economic sanctions adds to the list of objectives defined by the EC Treaty as sec-

${ }^{63}$ T-315/01 Yassin Abdullah Kadiv Council of the European Union and Commission of the European Communities, Judgment of the Court of First Instance of 21 September 2005.

${ }^{64}$ T-306/01 Ahmed Ali Yusuf and Al Barakaat International Foundation $v$ Council of the European Union and Commission of the European Communities, Judgment of the Court of First Instance of 21 September 2005.

65 The first of the Council Regulations (467/2001) was adopted only on the basis of articles 60 and 301 EC, whereas the second (881/2002) was adopted based on Articles 301, 60 and 308 EC. The respective Regulations are Council Regulation (EC) 467/2001 of 6 March 2001 prohibiting the export of certain goods and services to Afghanistan, strengthening the flight ban and extending the freeze of funds and other financial resources in respect of the Taliban of Afghanistan, and repealing Regulation (EC) 337/2000 [2001] OJ L67/1, and Council Regulation (EC) 881/2002 of 27 May 2002 imposing certain specific restrictive measures directed against certain persons and entities associated with Usama bin Laden, the Al-Qaeda network and the Taliban, and repealing Regulation 467/2001 [2002] OJ L139/9. The two Council Regulations were amended by nine Commission Regulations: 1354/2001 [2001] OJ L182/15, 1996/2001 [2001] OJ L271/21, 2062/2001 [2001] OJ L277/25, 2199/2001 [2001] OJ L295/16, 2373/2001 [2001] OJ L320/11, 2604/2001 [2001] OJ L345/54, 65/2002 [2002] OJ L11/3, 105/2002 [2002] OJ L17/52 and 362/2002 [2002] OJ L58/6.

${ }^{66}$ UNSC Resolutions 1267(1999), 1333(2000) and 1390(2002). 
ond-pillar objectives. If, however, it were decided that these two articles pursue second-pillar objectives, this would actually change the scope (and the wording!) of Article 308 EC. ${ }^{67}$ Second, restricting the movement of capital and payments did not concern third countries here, but rather a terrorist group (the Taliban) and those associated with it; the second question is, therefore, whether economic sanctions can be imposed on individuals who are third-country nationals. The third question, which arose only in the Yusuf case, is whether such sanctions may be imposed not only on third-country individuals, but also on EU citizens allegedly connected with such terrorist groups.

It should not be forgotten that all three problems actually stem from the fact that these regulations were implementing Security Council resolutions, and that the latter actually dictated the subject and scope of implementation. Thus, although the Union itself decided to implement these resolutions, the UN acts influenced the scope of the Union's competence. The Union could, however, have taken a different approach, declaring that the area regulated by the resolutions exceeded its competence and refusing to implement them, thus leaving the task of implementation to the Member States.

\subsection{The objective of economic sanctions}

With regard to the question of which goals were being pursued by the measure, the CFI was faced with a choice among three possible decisions. In the first, the objective of economic sanctions against the Taliban becomes a Community objective as a matter of fact once measures pursuant to Articles 301 and $60 \mathrm{EC}$ are adopted. By virtue of the fact that Article $301 \mathrm{EC}$ was included in the EC treaty, a CFSP objective included in a common position or joint action on whose basis a final economic sanctions measure is adopted becomes a Community objective as a matter of fact when that measure is adopted based on Articles 301 and 60. In the same way as the measure is transformed from a second-pillar measure to a Community one, the objective underlying it is transformed into a Community objective. The drawback of this argument is that there is a danger of foreign policy objectives becoming Community objectives in general, since any objective of an initial measure (common position or joint action) could become the objective of a subsequent Community measure.

In the second possibility, economic sanctions against the Taliban are said to pursue an objective of the Union manifested through a Community measure. This is the approach adopted by the CFI:

67 This is prohibited verbatim by Opinion 2/94 [1996] ECR I 1759. 
Under Articles $60 \mathrm{EC}$ and $301 \mathrm{EC}$, action by the Community is therefore in actual fact action by the Union, the implementation of which finds its basis on the Community pillar after the Council has adopted a common position or a joint action under the CFSP. ${ }^{68}$

This approach is problematic due to the fact that application of Article $308 \mathrm{EC}$ to articles regulating economic sanctions means not only a change and stretching of the latter, but also a change in the wording of Article 308 EC which, all at once, concerns not only Community but also Union objectives. The difference here from the first approach is that the former claims that action by the Community is not, in actual fact, action by the Union, but rather that Union objectives have become, in actual fact and for the purposes of Articles 60 and 301, objectives of the Community. The second approach states that these objectives remain Union objectives. The Court's argumentation also reveals a certain vision of the Union; namely, the Court sees the Union as an entity separate from the Community, not as an entity overarching it, expressly defining the Union and the Community as "integrated but separate legal orders". ${ }^{69}$ In order to avoid abuses of Article 308, the Court also stresses that:

...it appears impossible to interpret Article $308 \mathrm{EC}$ as giving the institutions general authority to use that provision as a basis with a view to attaining one of the objectives of the Treaty on European Union. ${ }^{70}$

It is important to stress that the two articles (301 and 60) must somehow be fitted into the framework of the EC Treaty; otherwise, it would perhaps be better to leave them out of it altogether.

The third option for the CFI was to argue that Article 308 cannot be applied to Community economic sanctions at all, and that such acts are always ultra vires. The Court would thus adopt a formalistic approach, thereby stating that any application of Article 308 EC to Community economic sanctions would amount to an ultra vires measure. This last approach arguably best conforms, in a literal sense, to Opinion 2/94, in which the Court determined that Article 308 "cannot serve as a basis for widening the scope of Community powers beyond the general framework created by the provisions of the Treaty as a whole and, in particular, by those that define the tasks and the activities of the Community". ${ }^{71}$ However, such an approach would be too rigid and would not reflect real-world requirements and demands, according to which states cannot be seen as the only source of security threats, given the fact that terror-

68 Kadi (n 63) para 125.

69 Ibid para 120.

70 Emphasis added, ibid.

${ }^{71}$ Opinion 2/94 (n 67) para 30. 
ist groups cannot be limited to the territory of one or several states, and may even lack a specific connection to a particular state. In practice, it would mean that the Union would not have the competence to implement any SC resolutions requiring it to go beyond the text of Articles 301 and 60. This would exclude implementation of any "smart sanctions" targeting individuals, the use of which has increased over the past decade. ${ }^{72}$ It must also be recognised that, at the time when Articles 301 and 60 EC were framed, all potential sources of security threats had probably not even been anticipated, and smart sanctions were not common practice. These two articles were introduced into the 1992 Maastricht Treaty as Articles 228a and 73g EC, at a time when smart sanctions were only being developed. In this regard, it was logical for the possibility of sanctions against individuals not to be included in the Treaty's text at that time. As will be seen below, the Constitutional Treaty aimed to encompass this development by including the possibility of targeting individuals.

\subsection{Sanctions against third-country individuals}

With regard to whether economic sanctions can be imposed not only against third countries, but also against individuals from third countries, it may, in our view, successfully be argued that an interpretation of Articles 301 and 60 covering third-country individuals can be fitted into the "framework of the Treaty". ${ }^{73}$ It must be borne in mind that the reality of international threats has changed since these two articles were introduced into the EC Treaty. Such threats are posed not only by states, but also by organisations originating in a particular country but not necessarily connected with it, or even independent of any country. The reason why Articles 301 and 60 refer only to third states is that, at the time of their framing, threats extending beyond national borders were not particularly imminent.

Such an interpretation is also in accordance with the provisions of the Constitutional Treaty, which is an important indicator and herald of the (necessary) development of legislation in this direction. Article III322(2) CT, ${ }^{74}$ which, if the Constitutional Treaty were ratified, would replace Article 301, stipulates in its second paragraph that the Council may "adopt restrictive measures [...] against natural or legal persons and

\footnotetext{
72 On smart sanctions see, for example, D Cortright and GA Lopez (eds), Smart Sanctions. Targeting Economic Statecraft (Rowman and Littlefield Publishers, Lanham 2002) and the literature cited therein.

73 Opinion 2/94 (n 67).

${ }^{74}$ For a comment on this article in connection with the Court's jurisdiction, see T Tridimas, 'The ECJ and the Draft Constitution: A Supreme Court of the Union?' in Tridimas and Nebbia (n 57) 128. See also R Smits, 'The European Constitution and EMU: An Appraisal' (2005) 42 CML Rev 425, 437ff.
} 
nonState groups or bodies" where a European-level decision provides for such measures. Article III-160(1) CT, which would replace Article 60 EC, states the following: "[A]s regards preventing and combating terrorism and related activities, European laws shall define a framework for administrative measures with regard to capital movements and payments, such as the freezing of funds, financial assets or economic gains belonging to, or owned or held by, natural or legal persons, groups or nonstate entities". Naturally, the CT provisions should not be used to interpret the provisions of the existing Treaties; nonetheless, they show in which direction the CFSP ought to develop should it be ratified by all the Member States.

\subsection{Sanctions against EU citizens}

The question of the permissibility of imposing sanctions against EU citizens arose in the Yusuf $f^{75}$ case, where the applicant, Ahmed Ali Yusuf, was a Swedish national, and the other applicant, Al Barakaat International Foundation, an economic entity established in Sweden. The CFI did not enter into a broader discussion of this issue, but simply relied on the effectiveness argument, determining that Articles 60 and $301 \mathrm{EC}$ would not be effective unless it were also possible to adopt measures "against individuals who, although not resident in the third country in question, are sufficiently connected to the regime against which the sanctions are directed". ${ }^{76}$ The CFI then addressed the specific situation of EU citizens by merely stating that "the fact that some of those individuals so targeted happen to be nationals of a Member State is irrelevant, for, if they are to be effective in the context of the free movement of capital, financial sanctions cannot be confined solely to nationals of the third country concerned". ${ }^{77}$

The decision to implement Security Council resolutions at the Union level, and not leave it to the individual Member States, constitutes a double stretching of Community competence. On the one hand, it allows

\footnotetext{
${ }^{75}$ Two other Swedish citizens, Abdi Abdulaziz Ali and Adirisak Aden, were removed from the list of persons subject to the freezing of funds. This was done due to a decision by the Sanctions Committee and, subsequently, at the Community level by Commission Regulation (EC) 1580/2002 of 4 September 2002 amending for the second time Council Regulation (EC) 881/2002 imposing certain specific restrictive measures directed against certain persons and entities associated with Usama bin Laden, the Al-Gaida network and the Taliban, and repealing Council Regulation (EC) 467/2001 [2002] OJ L237/3. These two applicants therefore decided not to pursue the case, and their names were removed from case $\mathrm{T}$ 306/01 (n 64).

${ }^{76}$ Yusuf (n 64) para 115. Further, in para 116, the CFI decided the following: "That interpretation, which is not contrary to the letter of Article $60 \mathrm{EC}$ or Article $301 \mathrm{EC}$, is justified both by considerations of effectiveness and by humanitarian concerns".

77 Ibid para 115.
} 
sanctions to be imposed against persons who are not nationals of the third country primarily targeted; on the other, it enables the stretching of Community competence to cover EU citizens. The Union and Community competences were, in a sense, determined by the content of the SC resolutions, and the Union decided to go beyond what the Treaty text provides rather than leave implementation to the Member States. Allowing targeted economic sanctions against EU nationals and stretching the scope of EC articles on economic sanctions against them could be problematic, however. First of all, it is questionable whether allowing targeted economic sanctions against EU citizens does not actually represent an amendment to the Treaty, which the Court explicitly prohibited in its Opinion 2/94, stating that Article 308 EC "cannot be used as a basis for the adoption of provisions whose effect would, in substance, be to amend the Treaty without following the procedure which it provides for that purpose". ${ }^{78}$ As the law stands at the present moment, sanctions may be adopted against third countries and - presumably, as argued above - against nationals of third countries. We are not arguing here that the Community should not, in the future, possess such a competence; we must warn, however, that any such purely judicially-driven competence could be problematic. Second, the CFI's reasoning could potentially raise another difficult question: namely, whether the Community has acquired the power to impose targeted economic sanctions against EU citizens in general, or only together with sanctions against third-country nationals. The adoption of sanctions based on Articles 60 and 301 EC would imply the latter, as would the CFI's reference to the fact that individuals must be "connected" with the regime targeted by the sanctions. Yet a broad (and purposeful) interpretation of the Court's position could well lead to a general competence for adopting sanctions against EU nationals.

It should be stressed that, by not giving the EU the power to freeze its citizens' assets, this competence would be unreasonably split among the Member States and the Union, with the former having the power to freeze assets of EU citizens, and the latter to freeze assets of other individuals outside the EU. In such a case, of course, it would be better for the Member States to freeze all the assets themselves; yet this would cause an unnecessary particularisation of competence, whereby SC resolutions would be implemented by the Union on one occasion, and on another by the Member States. Moreover, if a Member State did not implement the resolution properly, it could create a safe haven for financing terrorist organisations and make European citizenship a shield against sanctions. Again, the text of the Constitutional Treaty, which does not seem to restrict sanctions merely to those against third-country nationals, might

78 Opinion 2/94 (n 67) para 30. 
also be used as a guideline for interpretation and development of the law in this area. In any event, allowing the freezing of EU nationals' assets is one step towards stretching Community competences, with the Court once again, as so many times in the past, ${ }^{79}$ showing a willingness to read the Treaty expansively.

It should be added that one possibility available to the Court is to distinguish between the EU's competence to adopt acts alone and its competence to implement SC resolutions. Broadening competences solely to enable Member States to comply with SC resolutions could be based on their required compliance with international obligations, which would be facilitated by adoption of an act at the Community level. Broadening the Community's competences to adopt acts on its own, without any basis in a SC resolution, would, however, be more problematic.

\section{The future of the CFSP}

Regarding the degree to which the Member States might, in the future, confer their competences to the Union, it is important to discuss the future of the CFSP as well. Thinking about this is no easy task, particularly because one needs to avoid falling into the quite easy trap of simply transposing the Community method to this policy area. Divisions in the foreign policy area are too profound to be overcome by simply introducing qualified majority voting, supremacy and direct effect. Such measures would need to be supported by a broad political consensus, or else they would create even greater divisions among the positions adopted by the Member States. This part of the paper will thus examine two possible futures in this area: a model that tends more in the direction of "communalising" the CFSP (the collectivity model), and a model that works more to enhance flexibility within the CFSP (the flexibility model). The precondition for both models is political consensus on the basic issues; however, there is a difference between them as to how much competence the Member States must confer to the Union. In the flexibility model, the Member States will not need to confer their competences any more than at present, whereas under the collectivity model a further conferral of competence will be required. Both possible models of development also correspond to what was mentioned earlier (in the first part of this paper) regarding the stages of formation of a political union. The flexibility model means remaining at the synchronisation stage, whereas the collectivity model means moving into the harmonisation stage.

${ }^{79}$ The most obvious recent example of very broad interpretation of the Treaty is allowing the cumulative imposition of a lump sum penalty payment as a sanction against a Member State which failed to fulfil its obligations under the EC Treaty, in case C-304/02 Commission of the European Communities v French Republic [2005] ECR I-06263. 


\subsection{The flexibility model}

The first possibility for increasing the CFSP's effectiveness is to follow the path of enhanced flexibility within this policy. While it is true that flexibility is not a direct route towards harmonisation in the CFSP area, it might contribute to that end if a group of Member States proceeding in this direction were to be joined later by (certain) other Member States who had earlier opted out. However, greater flexibility could also be counterproductive and actually impede harmonisation. We advocate the view that it is more desirable to have at least some action by certain states than no action at all. Looking back at the table illustrating the stages of formation of a political union, we see that enhanced flexibility means remaining within the synchronisation stage. While it may perhaps be seen as an elaboration or variation of that stage, this does not mean that cooperation has advanced to the harmonisation stage. Greater flexibility can be achieved via two elements: constructive abstention and enhanced cooperation.

\subsubsection{How constructive is constructive abstention?}

The purpose of constructive abstention, as regulated by the TEU, is to prevent the occurrence of a deadlock situation in which the Member States are unable to proceed with an action in the CFSP area due to the opposition of one or more Member States. In theory, constructive abstention - allowing a Member State which abstains from voting not to be bound by the Council's decision, while this decision commits the Union provides for flexibility and has great potential for resolving disagreements among states. In contrast to "regular" abstention, which would not protect a Member State from the binding nature of a decision, Article 23(1) subparagraph 2 TEU allows it to make a formal declaration whereby it is not obliged to apply the Union's decision, although it is obliged to refrain from any action likely to conflict with or impede that decision. Constructive abstention thus seems to be an effective instrument for surmounting differences in the Member States' foreign policies. Despite this theoretical potential, however, the reality also indicates certain disadvantages of this instrument.

The first disadvantage is its actual effectiveness and use in practice. According to Ward, "the possibility of 'constructive abstention' has not yet been invoked by any Member State". ${ }^{80}$ We have verified this statement with the Council's public information service, which confirmed that

\footnotetext{
${ }^{80}$ I Ward, 'The Challenges of European Union Foreign and Security Policy: Retrospective and Prospective' (2005) 13 Tulane Journal of International and Comparative Law 5, 33, n 114.
} 
constructive abstention has indeed not been employed to date. ${ }^{81}$ In the majority of contested issues where collective action by the Member States is probably needed the most, use of constructive abstention is less likely, or not likely at all. Member States are inclined to protect their vital interests, prompting them to use a veto rather than constructive abstention. ${ }^{82}$ Although constructive abstention theoretically contributes to flexibility in the CFSP area, we would argue that it does not enhance this policy's effectiveness in practice. On the contrary, the rift between disagreeing states becomes even more obvious, and is less likely to be surmounted. ${ }^{83}$ While the possibility of constructive abstention should be maintained in the future, reliance on it should not be expected to provide a solution to the most contested issues. The question of how to convince the Member States to choose constructive abstention over a veto remains unanswered.

Second, there have been doubts as to whether a decision adopted with one Member State abstaining still bears the same credibility as a decision adopted unanimously. ${ }^{84}$ Indeed, there can be no doubt that credibility is not the same in these two cases; the question is whether the same degree of credibility should be sought at all. If we allow the possibility of a Member State's abstention from a vote, we must accept the diminished credibility of such a decision. In these cases credibility yields to effectiveness, with the success of such decisions definitely outweighing their potential lack of credibility.

Third, commentators have expressed fears of "free riding" with regard to financing CFSP actions, with Member States possibly deciding to abstain from voting in order to avoid financing a (military or defence) mission. ${ }^{85}$ Missiroli points out that "the costs of missions approved through 'constructive abstention' will be borne by the participating countries in accordance with their GDP, and not by the Community budget, unless

${ }^{81}$ The response from the public information service on was: "We were checking your question to some of our services and effectively, there was no 'constructive abstention' in the field of CFSP" (Personal e-mail correspondence 5 May 2006).

82 S Vanhoonacker, 'From Maastricht to Amsterdam: Was it Worth the Journey for CFSP?' (1997) 2 EIPASCOPE 6.

${ }^{83}$ Jaeger claims: "Compared to the pre-Amsterdam simple abstention, a grave disadvantage of constructive abstention is the introduction of a much more visible split in any foreign policy move of the EU”. T Jaeger, 'Enhanced Cooperation in the Treaty of Nice and Flexibility in the Common Foreign and Security Policy' (2002) 7 European Foreign Affairs Review 297, 299.

${ }^{84}$ A Missiroli, 'CFSP, Defence and Flexibility' (2000) Chaillot Paper 38, Institute for Security Studies of WEU <http://www.iss-eu.org/chaillot/chai38e.pdf> 9: "In fact, much as it makes good sense that a reluctant member state may simply refrain from action without blocking a sizeable majority of the others, how far can such a 'consensus minus $\mathrm{X}$ ' formula be stretched without undermining the credibility of the decision and its implementation?".

85 Ibid 10. 
the Council decides otherwise". ${ }^{86}$ When provisions on financing CFSP expenses are examined more closely, it is seen that this is true only for operating expenses concerning military or defence missions, and not for general CFSP expenses.

The administrative expenditures of institutions, which are not at issue here, are, in any event, financed from the EC budget. ${ }^{87}$ According to the second sentence of Article 268(2) EC, operating expenses occasioned by the implementation of provisions relating to the CFSP may, under the conditions set forth in the TEU, be financed from the budget. The TEU further specifies when these expenses should indeed be so financed. According to the first paragraph of Article 28(3) TEU, operating expenses arising from implementation of CFSP-related provisions are financed from the budget of the European Communities, except for those arising from operations with military or defence implications, or where the Council has unanimously decided otherwise. In such cases where expenditures are not financed from the EC budget, they are, according to the second paragraph of Article 28(3) TEU, "charged to the Member States in accordance with the gross national product scale, unless the Council acting unanimously decides otherwise". However, this paragraph contains another exception, one relating directly to constructive abstention:

As for expenditures arising from operations having military or defence implications, Member States whose representatives in the Council have made a formal declaration under Article 23(1), second subparagraph, [i.e. constructive abstention] shall not be obliged to contribute to the financing thereof.

As may be seen, the use of constructive abstention with regard to military or defence operations can indeed be problematic in terms of their financing. Constructive abstention may be used in matters relating to foreign policy, as well as in those relating to defence; the latter are financed differently from the former. The second paragraph of Article 28(3) TEU specifically states that Member States which have used the constructive abstention option for a particular decision on military or defence matters are not obliged to contribute to financing such a mission. Thus it is true that free riding could occur in military or defence operations, but not in foreign policy operations, which are financed from the EC budget. The question that follows is whether the possibility of free riding on the financing of military or defence operations is great enough for this argument to stand. In our view, the argument does carry weight in view of the importance of military and defence operations, as well as the large sums of money they involve. Just to cite one example, the common costs

\footnotetext{
86 Ibid.

${ }^{87}$ First sentence of art 268(2) EC and art 28(2) TEU.
} 
of Operation Althea in Bosnia and Herzegovina amounted to EUR 71.7 million. ${ }^{88}$ However, due to the sensitive nature of this issue, participation in a military or defence operation - and consequently its financing - still remains a Member State's own decision.

Finally, it is debatable whether constructive abstention may be reconciled with Member States' duty of loyalty and mutual solidarity (Article 11(2) TEU). ${ }^{89}$ This provision also stipulates that they "shall refrain from any action which is contrary to the interests of the Union or likely to impair its effectiveness as a cohesive force in international relations". The duty of loyalty is an expression and underlying premise of the collectivity model (as explained below), where the Union's interests are set above narrow national interests. It represents the ideal of the CFSP which is to be strived for and the principle that should underpin de lege ferenda, or future legislation. Yet precisely due to its idealistic nature, it is not possible to realise this duty in practice, for the time being; and it goes without saying that, given the lack of enforcement mechanisms, it is not possible to enforce it. Thus, our conclusion is affirmative: constructive abstention does, strictly speaking, run counter to the duty of loyalty. However, this relationship is more correctly described as what the law should be than what the law is.

\subsubsection{Enhanced cooperation}

Compared to constructive abstention, enhanced cooperation, extended to the CFSP by the Treaty of Nice, perhaps has a more realistic potential for practical use. Enhanced cooperation is "aimed at safeguarding the values and serving the interests of the Union as a whole by asserting its identity as a coherent force on the international scene" (Article 27a TEU). Despite this, enhanced cooperation, however promising, also contains several weaknesses.

The first big hindrance to this instrument is that it may only be used in relation to implementation of a joint action or common position, not for adoption of CFSP acts themselves. As a general rule, the implementation of joint actions or common positions is decided on by a qualified majority. Enhanced cooperation thus only allows a smaller group of Member States - at least eight of them - to proceed with implementation of a decision previously adopted unanimously. Second, enhanced cooperation is not an instrument which may be used on a regular basis. Article 43a TEU,

88 This does not include personnel and other costs, which were referenced according to a "costs lie where they fall” basis. See G Grevi, D Lynch and A Missiroli, 'ESDP Operations' (2005) Institute for Security Studies of WEU <http://www.iss-eu.org/esdp/09-dvl-am.pdf> 7.

${ }^{89}$ Article 11(2) TEU: "The Member States shall support the Union's external and security policy actively and unreservedly in a spirit of loyalty and mutual solidarity". See also, for example, E Shaver Duquette, 'Will a Constitution for the European Union Make a Difference?' (2004-2005) 1 Loyola University Chicago International Law Review 71. 
inserted by the Treaty of Nice, requires that it be "undertaken only as a last resort", when the objectives of such cooperation cannot be achieved by regular means. Thus, the occasions on which enhanced cooperation is actually used cannot be too numerous. Third, even enhanced cooperation could be blocked by a Member State for important declared reasons of national policy. Every instance of enhanced cooperation requires the Council's authorisation. Despite the fact that such authorisation is granted by a qualified majority (Article 27e(2) TEU), in the CFSP area the Council will still act in accordance with the provisions on QMV (Article 27c in connection with the second subparagraph of Article 23(2) TEU), which allow a Member State "to oppose the adoption of a decision to be taken by qualified majority" for reasons of national policy.

How should enhanced cooperation evolve in the future, so as to contribute to the effectiveness of the CFSP? Its weaknesses would need to be overcome, i.e. its use should be allowed not only for implementation, but also for CFSP decisions themselves; ${ }^{90}$ the possibility of vetoing enhanced cooperation should be eliminated; ${ }^{91}$ and use of this option should be stimulated and supported. ${ }^{92}$ It is true, as Jaeger ${ }^{93}$ points out, that using this type of cooperation for main decisions - and not only implementing ones could lead to the fragmentation of foreign policy. Yet such fragmentation is a necessary corollary of the exercise of enhanced cooperation, whose essence is that a group of Member States proceeds with a common action that the others do not wish to participate in. Such fragmentation is, in any case, softened by the requirement of prior authorisation of such cooperation by the Council.

The flexibility model can serve as the forerunner to a subsequent collectivity model, or it can exist concurrently with a deepening of the collectivity model, as will be discussed below.

90 F Algieri, J Emmanouilidis and C Giering, 'Flexibility in EU Foreign and Security Policy' (2003) Centre for Applied Policy Research and Bertelsmann Foundation, Convention Spotlight 2003/2 <http://www.cap.uni-muenchen.de/download/spotlight/Spotlight_0203_e.pdf $>, 2$. The same paper also correctly claims (p 4) that "the fact that the flexibility instruments already contained in the treaty have not been extensively utilised in the past demonstrates that the present treaty regulations and instruments are insufficient".

91 Ibid.

${ }^{92}$ Colino emphasises that practical use of this mechanism has not been encouraged sufficiently. SM Colino, 'Towards greater flexibility or deadlock? The progress of European integration since the introduction of enhanced cooperation' (2004) The Federal Trust for Education and Research, Online Paper 24/04 <http://www.fedtrust.co.uk/uploads/constitution/24_04.pdf> 3: "[T]he original formulation in the Treaty of Amsterdam was a 'dead letter', and even the Nice reform does not necessarily provide much more encouragement to put this mechanism into practice".

${ }_{93} \mathrm{~T}$ Jaeger, 'Enhanced Cooperation in the Treaty of Nice and Flexibility in the Common Foreign and Security Policy' (2002) 7 European Foreign Affairs Review 297, 302, citing Peers, 'Common Foreign and Security Policy 1999-2000' (2001) 20 Yearbook of European Law 531, 552. 


\subsection{The collectivity model}

The second possible direction for enhanced effectiveness of the CFSP is continuing to deepen the collectivity of CFSP decisions and strengthening cooperation, loyalty and solidarity among the Member States by introducing concurrent competences and qualified majority voting in this area. As mentioned above, on the scale of stages in the formation of a political union the collectivity model represents a transition to the harmonisation stage.

\subsubsection{Introducing concurrent competences}

It should be stressed at the outset that introducing an exclusive competence is not necessary for an effective CFSP, nor is it desirable at this stage of the policy's development. The same does not apply to concurrent competences. However, although introducing concurrent competences is one of the prerequisites for a more effective CFSP, the decision to proceed with it should be taken upon due reflection, bearing in mind what such competences imply.

Following the introduction of concurrent competences, the Member States would, of course, retain their own relations with third states, while EU competences would be used when action by all the Member States is required, e.g. in times of crisis, the need for humanitarian intervention, supervising elections, and the like - any time when collective action represents an effective response to a crisis. The most important difference from the current type of CFSP competence is that the Member States would be pre-empted from acting in this area once the Union has acted. This could mean that, should the Union adopt acts against terrorism, the Member States should refrain from adopting acts in that particular area. Moreover, concurrent competences as currently conceived go hand in hand with the supremacy of acts adopted at the Community level. Of course, it might be argued that supremacy could be excluded in the case of the CFSP; but if one or another level of decision-making were not to effectively "occupy" this area, would the actual functioning of concurrent competences not be impaired?

In order for the Union not to overstep the boundaries of its competence, the principle of subsidiarity should be adequately reinforced, as explained below. The lines in the sand, to borrow an expression from Eileen Denza, ${ }^{94}$ are thus not those between a common and a single foreign policy, but between the Member States' and the Union's competences in particular areas. The call for a single foreign policy is, therefore,

${ }_{94}$ E Denza, 'Lines in the Sand: Between Common Foreign Policy and Single Foreign Policy' in Tridimas and Nebbia (n 57) 259. 
a misguided one. A single foreign policy for the Union would require introducing an exclusive competence, something which, as argued at many intervals in this paper, should not happen.

\subsubsection{Expanding qualified majority voting}

Probably the most important step towards a more effective CFSP is the introduction of qualified majority voting for a broader scope of issues in the CFSP area. Currently, unanimity is the general voting rule for CFSP actions. As already mentioned above, qualified majority voting can only be used in three instances: when adopting joint actions, common positions, or any other decision on the basis of a common strategy; when adopting any decision implementing a joint action or common position; and when appointing a special representative (Article 23(2) TEU). Expansion of QMV could occur in a general manner, with QMV serving as the general rule and unanimity as the exception, whereby the safeguard allowing decisions to be blocked for important national policy reasons would be maintained. Another possibility for expanding QMV, as suggested by Pernice and Thym, would be to define specific CFSP areas in which QMV would be used, enumerating in detail which issues would permit its use. ${ }^{95}$

QMV in the CFSP area is another instrument that works very well in theory, acting like a magic wand to resolve all disharmony among the Member States' foreign policies. However, in practice the introduction of QMV in this area is faced with immense obstacles, and Menon correctly cautions that "wishful thinking should not be allowed to blind us to the realities of the situation". ${ }^{96}$ The introduction of QMV in the CFSP area requires an immense shift in the Member States' political positions, particularly among its strongest opponents, France and the United Kingdom. ${ }^{97}$ In contrast, Germany, Italy and the Benelux countries are more in favour of such an approach. Another downside to introducing QMV in this area reveals itself in a comparison with first-pillar QMV: in the latter case, a Member State that is outvoted can challenge the decision before the ECJ, a possibility which is not allowed with regard to the CFSP, as the Court does not have jurisdiction in this area. Thirdly, introducing QMV might lead to insurmountable divisions among the Member States, ${ }^{98}$ much greater than those created by enhanced cooperation. For the time be-

\footnotetext{
95 I Pernice and D Thym, 'A New Institutional Balance for European Foreign Policy?' (2002) 7 European Foreign Affairs Review 369, 379f.

96 A Menon, 'Towards an Effective CFSP: Institutional Proposals' (2003) Contribution to Convention Forum <http://europa.eu.int/constitution/futurum/documents/other/ oth040203_2_en.pdf>, 3.

97 Vanhoonacker (n 82) 6.

98 Menon (n 96) 3.
} 
ing, strengthened flexibility in the CFSP area is both more desirable and more appropriate than QMV, which would most likely not even be used in contested issues. Enhanced flexibility, rather than the bindingness of measures on states which have voted against them, is a more appropriate instrument for such a sensitive area as foreign policy, at least at this stage of its development. In the future, however, the introduction of $\mathrm{QMV}$ will be necessary to enable the CFSP to move ahead towards forming a political union and taking a more active role in international politics. The Constitutional Treaty indicates a further step in this respect. QMV will also be possible when adopting a European decision defining a Union action or position, based on a proposal made by the Minister of Foreign Affairs following a specific request from the European Council. ${ }^{99}$

\section{Concluding remarks}

This paper has attempted to clarify the answer to questions regarding the nature of the second pillar, and to prove that the CFSP can be treated as neither an intergovernmental nor a supranational model. By demonstrating that the Union possesses convergent competences in the CFSP area and explaining the characteristics of this type of competence, it has sought to prove that the CFSP is more than just simple cooperation among the Member States. In a more general manner, we have tried to set forth general criteria as to when a conferral of competence from the members of an entity to the entity itself takes place. Furthermore, our purpose has been to show that the introduction of an exclusive competence and the creation of a single European foreign policy are not necessary in order to ensure the CFSP's effectiveness and further development. The Union is still a long way from creating a full political union, and, at this point in time, it is doubtful whether such a union is desirable at all. ${ }^{100}$ It has been argued here that if the Union does indeed wish to move forward towards the creation of a political union, it should first introduce concurrent competences and qualified majority voting in this area. However, such steps towards political union should not be mere words in a revised version of the treaties; they should be an active, living force that will give the Union the ability to react rapidly to crises in the world, contribute to world peace, and promote the values of democracy, human rights and the rule of law. This will not be achieved by merely regulating the technicalities, but rather by a clear, penetrating vision of the Union's international role, one which can be achieved only if differences in national policies are overcome by striving for common action, coupled with the awareness that

\footnotetext{
99 Treaty establishing a Constitution for Europe art III-300(2)(b).

${ }^{100}$ Verheugen foresees its creation in twenty years. See 'Verheugen predicts political union in 20 years' < http://www.euobserver.com/9/20941> accessed 20 February 2006.
} 
only through such common action can the Union make progress in its foreign policy and respond to problems abroad. Another direction that the Union could take in the second-pillar area is to deepen its flexibility by strengthening enhanced cooperation and stressing the use of constructive abstention. This might not suffice in the long run, however, given the ever greater need for responses to a wide variety of world problems. New demands for action in the foreign policy area also require adjustments within the framework of first-pillar competences. The introduction of "smart sanctions" which target individuals by freezing their funds and assets has confronted the Union with a new task, requiring adaptation of the scope of first-pillar competences. When implementing UN Security Council resolutions in these matters, the Community must broaden its first-pillar competences in order to successfully respond to such world political demands. With regard to further integration in the CFSP area, the Union will hopefully find a way to balance the Member States' desire for control over foreign policy issues, on the one hand, and the effectiveness of its own foreign policy, on the other, so as to play a stronger international role in the future. 
